OPEN ACCESS

Edited by:

Roberto Sulpizio

Università degli Studi di Bari Aldo

Moro, Italy

Reviewed by:

Claudio Scarpati,

University of Naples Federico II, Italy

Young Kwan Sohn,

Gyeongsang National University,

South Korea

*Correspondence:

Greg A. Valentine

gav4@buffalo.edu

Specialty section: This article was submitted to

Volcanology,

a section of the journa

Frontiers in Earth Science

Received: 29 June 2017

Accepted: 14 August 2017

Published: 30 August 2017

Citation:

Valentine GA, White JDL, Ross P-S, Graettinger AH and Sonder I (2017)

Updates to Concepts on

Phreatomagmatic Maar-Diatremes and Their Pyroclastic Deposits.

Front. Earth Sci. 5:68.

doi: 10.3389/feart.2017.00068

\section{Updates to Concepts on Phreatomagmatic Maar-Diatremes and Their Pyroclastic Deposits}

\author{
Greg A. Valentine ${ }^{1 *}$, James D. L. White ${ }^{2}$, Pierre-Simon Ross ${ }^{3}$, Alison H. Graettinger ${ }^{4}$ and \\ Ingo Sonder ${ }^{1}$
}

${ }^{1}$ Department of Geology and Center for Geohazards Studies, University at Buffalo, Buffalo, NY, United States, ${ }^{2}$ Geology Department, University of Otago, Dunedin, New Zealand, ${ }^{3}$ Institut National de la Recherche Scientifique, Québec, QC, Canada, ${ }^{4}$ Department of Geosciences, University of Missouri-Kansas City, Kansas City, MI, United States

Recent work is changing our understanding of phreatomagmatic maar-diatreme eruptions and resulting deposits. In previous models, explosions were often inferred to take place only at the base of a diatreme, with progressive downward migration due to a cone of depression in the host aquifer. However, diatremes themselves contain much water that is heterogeneously distributed, and field evidence supports the existence of explosion sites at many vertical and lateral locations within them. Crater sizes have been used to estimate explosion energies, but this only works for single-explosion craters where the depth of explosion is independently known, and has limited value for multi-explosion maar-diatremes. Deep-seated lithic clasts in tephra ring beds have been taken to indicate the depth of the explosion that produced that bed. However, only relatively shallow explosions actually vent to the surface, and deep-seated lithics are gradually brought to shallow depths through step-wise mixing of multiple subsurface explosions. Grain-size of tephra-ring deposits is often inferred to indicate fragmentation efficiency. However, other factors strongly influence deposit grain size, including the scaled depth of an explosion and the interaction of an erupting jet with topography around a vent (e.g., crater), along with long recognized effects of mechanical properties of host rocks and recycling within the vent/diatreme. These insights provide a foundation for future research into this important volcano type.

Keywords: maar, diatreme, phreatomagmatic, explosive eruption, crater, pyroclastic, tephra ring

\section{INTRODUCTION}

A grand challenge issue in volcanology is the need to advance our understanding of the mechanisms and effects of the interaction of magma with externally derived water. Maar-diatremes provide key natural experiments on these problems, as they are the type example of volcanoes that are dominated by explosive subsurface interaction of magma with groundwater (phreatomagmatic). Erosion of volcanic fields often exposes the subsurface structures of the volcanoes (diatremes), while relatively young fields preserve the craters (maars), which cut into the pre-eruptive landscapes, and their surrounding pyroclastic deposits (tephra rings). In some cases variable erosion has allowed both surface and subsurface features to be preserved. 
Phreatomagmatic origins are widely accepted for common maar-diatremes, which are typically basaltic but can range in composition to rhyolite (Austin-Erickson et al., 2008; Ross et al., 2017); these are the focus of this paper. Lorenz (1986) presented a model for maar-diatremes in which subsurface phreatomagmatic explosions begin at relatively shallow levels, and progressively deepen as aquifer groundwater is used up. Valentine and White (2012) summarized more recent evidence that explosions may not systematically deepen with time, but rather shift vertically and laterally as a diatreme develops, while shallowest explosions dominate the eruptive activity, and this is reflected in the crater morphology and tephra ring characteristics. A second model, which is not further discussed here, and which arose mainly from studies of ultramafic (especially kimberlitic) examples, argues that the volcanoes are produced primarily by the effects of magmatic gases which excavate a vent, followed by continued upward streaming of gas through vent-filling debris while diatreme walls fail and the structure grows (e.g., McGetchin and Ullrich, 1973; Woolsey et al., 1975; Sparks et al., 2006; but note that many authors argue for phreatomagmatic origins for ultramafic cases as well, e.g., White and Ross, 2011; Brown and Valentine, 2013; Kurszlaukis and Fulop, 2013).

Recent field research, experiments, and modeling have provided important new insights into the dynamics of phreatomagmatic maar-diatreme eruptions. This paper is structured around the three major features of the volcanoes: diatreme, crater, and tephra ring. Rather than providing a comprehensive review, the aim is to synthesize recent findings that modify some aspects of our way of thinking about these three major features of maar-diatremes.

\section{DIATREMES}

Diatremes can extend hundreds of meters to $>1 \mathrm{~km}$ below the surface, gradually tapering downward. The upper levels of diatreme structures commonly preserve stratified pyroclastic deposits, post-eruptive sediments, and colluvial material, all of which may dip inward (e.g., White, 1991). Deeper levels are generally non-bedded but may contain vertical domains with contrasting grain-size distribution and juvenile and lithic componentry (e.g., Ross and White, 2006; Figure 1A). Lithic clasts may be derived from a range of original levels in the country rock (e.g., Hearn, 1968; Lefebvre et al., 2013). The outer parts of diatremes commonly consist of subsided country rock (e.g., Hearn, 1968; Delpit et al., 2014). These deeper diatreme characteristics are inferred to result from multiple subsurface phreatomagmatic explosions (White and Ross, 2011). Intradiatreme intrusions are often relatively small and irregular in shape (e.g., McClintock, 2006; Befus et al., 2009; Valentine and van Wyk de Vries, 2014; Lefebvre et al., 2016). In previous
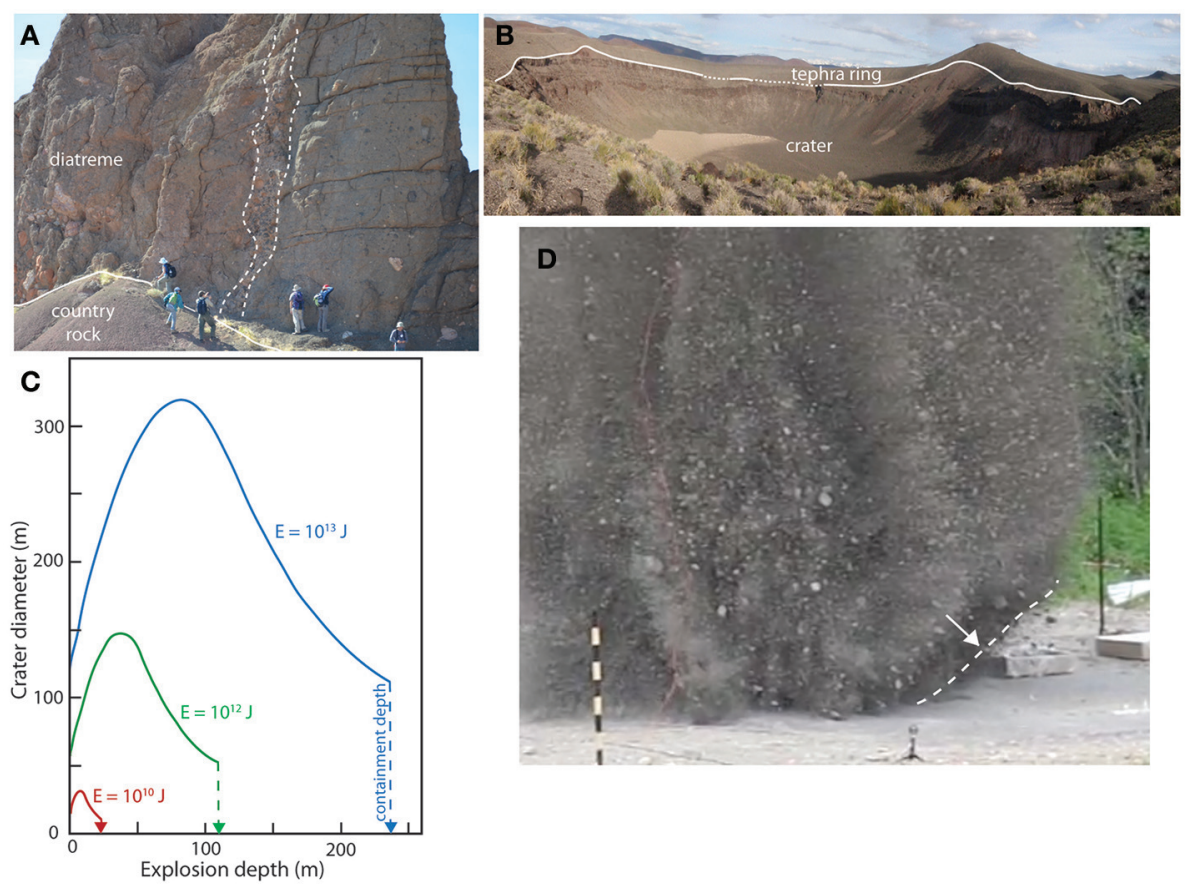

FIGURE 1 | (A) Subvertical lithologic domains (dashed lines) within a diatreme at a depth of 300 m below the eruptive surface (Standing Rocks West, Hopi Buttes volcanic field; see Lefebvre et al., 2013). Horizontal jointing is not related to any depositional structures. Example of a subvertical contact with country rock indicated by solid line. (B) Lunar Crater maar (Lunar Crater volcanic field; Valentine et al., 2011). Crater diameter is about 1 km. White line indicates contact between tephra ring and pre-eruptive surface (dashed where covered). (C) Predicted crater diameter as a function of explosion depth for three different explosion energies, for single-explosion craters (Modified from (Sonder et al., 2015), where variability in the predicted values is also discussed. No permission is required for revision or reproduction of the original figure.). The vertical dashed lines represent the containment depth, below which no crater is excavated. (D) Photograph from a subsurface explosion experiment, showing front of outward propagating ballistic curtain (dashed line) and motion of particles (arrow). 
models, explosions were inferred to take place primarily at the base of a diatreme (root zone), with progressive downward migration due to a cone of depression in the host aquifer; the host aquifer was considered to be the main source of water for phreatomagmatic explosions involving magma ascending along a dike (e.g., Lorenz, 1986).

\section{Past Inference-Diatremes Are Often Overlooked as Reservoirs of Water (Compared to Surrounding Aquifer)}

During eruptions, diatremes are bodies of unconsolidated juvenile and lithic material and can be expected to have significant water storage capacity and potentially high permeability. Water from adjacent aquifers is likely to keep a diatreme at least locally water saturated. Much of the material in eruptive jets collapses back into the crater, recycling liquid water caught up in an explosion back into the upper diatreme (White and McClintock, 2001). As magma enters a diatreme it is likely that the intrusion will wander and take on an irregular shape in the unconsolidated fill, and, if it does not explode, cause local drying and redistribution of water. Thus, we argue the diatreme itself serves as a heterogeneous aquifer through which intrusions ascend.

\section{Past Inference-Diatremes Are Fed at Their Bases by Ascending Dikes}

Dikes play important roles in feeding most volcanoes, including diatremes and other small volcanoes in volcanic fields. Recognition of sills in the upper half-kilometer of volcanic fields complicates this picture (Valentine and Krogh, 2006; Muirhead et al., 2016). Diatremes can form from these sills, or where inclined sheets or small magma diapirs ascend from the sills (Diez et al., 2009) and undergo subsequent phreatomagmatic explosions. Another complication is evidence for magma withdrawal in dikes connected with diatremes (Lefebvre et al., 2012; Re et al., 2016), severing the link between dike ascent and initiation of explosions. Thus, while many or most diatremes are rooted by dikes, explosions do not necessarily initiate during dike ascent, and sills, inclined sheets, and small diapirs can also be diatreme feeders.

\section{CRATERS}

Maar craters are typically tens to $\sim 200 \mathrm{~m}$ deep and have diameters of several hundred meters up to a few kilometers (e.g., Figure 1B). Some workers have assessed the use of crater size as a proxy for explosion energy (e.g., Taddeucci et al., 2010). Large craters often are clearly compound in that they comprise overlapping craters that form a single depression, and diatremes commonly provide evidence of both vertically and laterally shifting subsurface explosions (White and Ross, 2011).

\section{Past Inference-Crater Size Relates to Explosion Energy}

A key parameter for phreatomagmatic explosions is the range of mechanical energies involved and the efficiency with which magma's thermal energy is converted to mechanical energy. Data form a linear trend on a log-log plot of crater diameter $(D)$ from single explosions vs. energy ( $E$; Goto et al., 2001), but the $\log$ scale over 14 orders of magnitude obscures variability with factors of 10-100 in the data. Sonder et al. (2015) presented an empirical relation between scaled crater radius $\left(r_{s c}=R \cdot E^{-1 / 3}\right.$, where $R$ is the measured radius) and scaled depth $\left(d_{\mathrm{sc}}=\right.$ $d \cdot E^{-1 / 3}$, where $d$ is the physical depth of the explosion center), showing that scaled radius is maximum when $d_{\mathrm{sc}}=0.004 \mathrm{~m}$ - $\mathrm{J}^{-1 / 3}$ (see also Goto et al., 2001). Crater diameter does not uniquely equate to a value of energy for a given set of hostrock properties, i.e., the same crater size can be produced by different energies at different scaled depths, and a single energy produces different diameters depending upon its depth (Figure 1C). In the absence of independent data on the depth of an explosion it is not possible to uniquely constrain its energy based upon crater diameter. Compounding this is the fact that most maar-diatremes show evidence of having been produced by numerous explosions, presumably with a range of energies. Sonder et al. (2015) concluded that, in multiexplosion craters in which explosions migrate only in the vertical dimension, the diameter cannot be simply related to either the cumulative energy of explosions or the energy of the single largest explosion. These problems become even less tractable when explosions shift both vertically and laterally, as probably happens in most natural maar-diatremes. Thus, we conclude that crater sizes are not a useful proxy for explosion energy at maar-diatremes.

\section{Past Inference-Maar-Diatremes, Especially Those with Large Craters, Commonly Feature Multiple Eruptive Loci (Epicenters)}

The field evidence for this includes: observations of the 1977 eruptions of Ukinrek maars, where two vents were observed erupting simultaneously within the East Maar (Self et al., 1980); clearly scalloped perimeters and multiple circular depressions on the floors of large maars (e.g., Begét et al., 1996); and reconstructed ballistic trajectories of tephra-ring blocks that point to multiple eruption sites (Jordan et al., 2013). Recent work provides further insight into the effects of multiple epicenters. The maximum diameter of a crater $\left(D_{\text {ref }}\right)$ made by an explosion of energy $E$ is $D_{\text {ref }}=\left(0.014 \mathrm{~m} \cdot \mathrm{J}^{-1 / 3}\right)$. $E^{1 / 3}$ (Goto et al., 2001), which we refer to as the reference footprint of an explosion (Valentine et al., 2015). Experiments suggest that, when explosions all have epicenters within each other's reference footprints, the result will be a circular crater. If two explosions have overlapping reference footprints but each epicenter is outside the other explosion's footprint, the surface expression will be a single compound crater with an irregular shape. Separate craters form when reference footprints do not overlap at all (Valentine et al., 2015). This information can be used to assess the combination of explosion energies and lateral distances between explosions. For example, a circular crater implies that the lateral distances between explosions were centered within circles defined by $D_{\text {ref }}$, for all of the 
individual explosion energies involved. Thus, crater morphology can provide semi-quantitative information on the combinations of explosion energies and lateral distances between explosion loci.

\section{TEPHRA RING}

Maar craters are surrounded by low-profile tephra rings (e.g., Figure 1B) with pyroclastic deposits ranging from massive tuff breccias to bedded and cross-bedded tuffs and lapilli tuffs, with abundant clasts emplaced from ballistic trajectories. These lithicrich deposits are often suggestive of eruptions dominated by discrete, short-lived explosions rather than by sustained eruption columns and fountains, often with interbedded or late-stage products of processes produced by magmatic volatile-driven activity (e.g., scoria fallout, lava flows).

\section{Past Inference-Deepest-Seated Lithic Clasts in Tephra-Ring Deposits Record the Depth of the Diatreme}

Most tephra rings are rich in lithic clasts derived from the rocks beneath a maar. Within Lorenz's (1986) framework for maardiatremes, the appearance of deeper-seated lithic clasts in the upper tephra-ring deposits was taken as an indicator of the progressive deepening of explosion loci and of the diatreme bottom, with an implication that the bed containing a given deepseated lithic clast was produced by an explosion at the depth of origin of that clast.

The effects of scaled depth on subsurface explosions pose a major roadblock for this interpretation. As scaled depth increases beyond the optimal cratering value of $\sim 0.004 \mathrm{~m}$. $\mathrm{J}^{-1 / 3}$ the amount of material ejected and the crater size progressively decrease until $d_{\mathrm{sc}}=0.008 \mathrm{~m} \cdot \mathrm{J}^{-1 / 3}$; larger scaled depths produce fully contained explosions from which no material is ejected (Graettinger et al., 2014). Valentine et al. (2014) assessed the range of explosion energies that might be expected at maar-diatremes and concluded that realistic magma-water explosions will only erupt material when their depths are less than $\sim 200 \mathrm{~m}$. Furthermore, deposition of erupted material onto a tephra ring requires most explosions to occur at depths of $\sim 100 \mathrm{~m}$ or less. Tephra-ring lithic clasts that originate at depths of a few hundred meters are not ejected directly from explosions at those depths. Rather, repeated subsurface explosions at a range of depths cause both upward and downward mixing via debris jets and subsidence (Ross et al., 2008a,b; Sweeney and Valentine, 2015; Andrews et al., 2016). This step-wise mixing takes time, explaining why deep-seated lithic clasts normally occur late in a tephra ring sequence; in some cases an eruptive episode might end before deep-seated clasts have mixed to shallow levels, thus leaving no eruptive record of that part of the diatreme. We conclude that deeper-seated lithic clasts in tephra rings are the result of gradual upward mixing of wall-rock clasts, and they represent, at best, the minimum vertical extent of an underlying diatreme.

\section{Past Inference-Grain Size of Tephra-Ring Bed Reflects Fragmentation Efficiency of the Explosion That Produced the Bed}

Papers on tephra-ring deposits often equate the grain size of a given facies to the efficiency of fragmentation (e.g., Clarke et al., 2009; Jordan et al., 2013). This implies that the deposit grain size results only from the fragmentation process at the site of magmawater interaction. However, other factors play important roles in the grain size of deposits at a given location in a tephra ring, including the scaled depth of an explosion, which determines how far the jet is able to throw coarse material, and the presence or absence of a pre-existing crater for a given explosion (e.g., Graettinger et al., 2015b). Eruptive jets through the debris fill at the centers of existing craters, such as would occur after initial maar-diatreme development, tend to be vertically focused and collapse back into the crater rather than onto the tephra ring (Taddeucci et al., 2013). When the jet collapses and rapidly sediments onto the crater floor, it expels gas and fine ash which then feed laterally flowing, fine-grained density currents (base surges; Graettinger et al., 2015b), leaving coarser deposits in the diatreme (Lefebvre et al., 2013). Such processes would be expected at the natural scale to produce fine-grained pyroclastic surge deposits and ash fallout in a tephra ring; however, there is no implication at all about the efficiency of fragmentation during the explosion.

Additional factors in the grain size of tephra ring deposits include: (1) host materials and how they disintegrate during explosions (e.g., weakly- or non-consolidated fine-grained sediments, compared to competent granitic hosts; e.g., Blaikie et al., 2012); (2) the duration of activity and the number and energies of explosions that progressively break up country rocks and recycled juvenile material; and (3) the amount of recycled material that is fragmented, ejected, and then deposited back into the crater to undergo subsequent explosions and associated fragmentation (e.g., Houghton and Smith, 1993). The grain size characteristics of a tephra-ring bed can reflect a long and complicated history of subsurface explosions, even if that bed is the deposit of a single explosion. Some proportion of the clasts do not make it onto the tephra-ring, but rather return to the crater and diatreme, resulting in an exaggeration of fine-grained components in tephra rings (White and Valentine, 2016). Thus, we conclude that grain size of tephra ring deposits is not a good proxy for fragmentation efficiency.

\section{Past Inference- "Magmatic" Deposits Interbedded in Tephra Rings Represent Lack of Water Supply, or Temporary Drying Out of System}

Many tephra rings contain both products of phreatomagmatic explosions and of those potentially driven by magmatic volatiles, for example, agglomerates (but see White and Valentine, 2016), scoria fall layers, and terminal lava flows or scoria cones. This is often interpreted to be the result of groundwater depletion (e.g., Lorenz, 1986).

Other key factors enable magmatic-volatile driven activity during a maar-diatreme's eruptive episode. First, magma-water 
interaction depends not only upon water availability, but also on magma flux and other factors that are poorly understood and difficult to infer from nature, such as the geometry of an intrusion of a given batch of magma into a diatreme. Some dikes may not encounter wet parts of a diatreme, for example if a preceding intrusion(s) locally dried or sealed off water from the path of an incoming dike, and so make it to the surface with no phreatomagmatic interaction or interact in the subsurface without explosion, while other dikes intersect wet diatreme fill under the right conditions and do explode. It seems likely that, if magma flux temporarily increases during an eruption, it might overwhelm the effects of water and rise directly to the surface to feed Strombolian or Hawaiian styles of activity. Additionally, multiple vents can be active simultaneously within a maar. Ukinrek East Maar activity had simultaneous steam and ash emissions and Strombolian activity from two vents within the single crater (Self et al., 1980). Thus, we conclude that the presence of deposits from magmatic-volatile driven activity is not a simple indicator of the availability of groundwater from host aquifers.

\section{Past Inference-Tephra-Ring Deposits Are Mainly Related to Pyroclastic Density Currents and Fallout}

The importance of pyroclastic density currents (PDCs), especially dilute ones (a.k.a. pyroclastic surges), in tephra-ring deposits has been recognized since the seminal work of Moore et al. (1966) and Fisher and Waters (1970), and some deposits indicate deposition from concentrated PDCs (e.g., White, 1991). Well sorted, topography-mantling fallout deposits are also widely recognized in tephra rings, as are individual blocks and bombs that were emplaced ballistically.

Another mechanism is ballistic curtains, which form when discrete eruptive jets simultaneously collapse and expand radially. Particles in the ballistic curtain follow ballistic paths, but proximally as dispersions rather than as isolated clasts. Deposition occurs both downward and outward at a given point (Figure 1D). Proximal deposits in field-scale experiments were massive and poorly sorted, and varied in thickness and coarseness in the circumferential direction; these graded laterally into sheet-like deposits that may resemble fallout and finally to individual scattered clasts distally (Graettinger et al., 2015a,b). Proximal, poorly sorted tuff breccias at some maars (e.g., Sohn and Chough, 1989) may have been emplaced by ballistic curtain mechanisms. Ballistic curtain deposits are expected to be favored early in the development of a maar because, as the crater deepens and grows, jets become increasingly vertically focused if they are centered in the crater, or inclined if they are off-center (e.g., Valentine et al., 2015); both factors decrease the effectiveness of the ballistic curtain mechanism. We conclude that there are likely four distinct

\section{REFERENCES}

Andrews, R. G., White, J. D. L., Dürig, T., and Zimanowski, B. (2016). Simulating maar-diatreme volcanic systems in bench-scale experiments. J. Geol. Soc. 173, 265-281. doi: 10.1144/jgs2015-073 mechanisms that contribute to tephra ring deposition: pyroclastic density currents, fallout, individual ballistic clasts, and ballistic curtains.

\section{SUMMARY}

To summarize, the following points provide important updates to our understanding of phreatomagmatic maar-diatreme volcanoes:

- Diatremes serve as reservoirs that can provide water for intradiatreme explosive interaction with ascending magma.

- Magma may be diverted laterally into both sills and dikes in the upper half kilometer below surface, and these shallow features can in turn feed diatremes.

- Crater sizes are not a useful proxy for explosion energy at maar-diatremes.

- Crater morphology can provide semi-quantitative information on explosion energies and the degree of lateral shifting of explosion loci.

- Deeper-seated lithic clasts in tephra rings are the result of gradual upward mixing of wall-rock clasts, and they represent, at best, minimum depth of an underlying diatreme.

- Grain size of tephra-ring deposits is not good proxy for fragmentation efficiency

- The presence of deposits from magmatic-volatile-driven activity is not a simple indicator of the availability of groundwater from country-rock aquifers.

- Ballistic curtains are an additional distinct mechanism for deposition in tephra rings, in addition to pyroclastic density currents, fallout, and ballistic emplacement of individual blocks and bombs.

Maar-diatremes remain a ripe source of information on phreatomagmatic activity, which can then be transferred to other volcanic systems.

\section{AUTHOR CONTRIBUTIONS}

All five authors contributed to the concepts and perspectives presented in the paper. GAV led the writing of the manuscript iteratively with each of the co-authors.

\section{ACKNOWLEDGMENTS}

This work was supported by U.S. National Science Foundation grant EAR-1420455 (GV) and by the University at Buffalo (AG), and a Discovery Grant from the Natural Sciences and Engineering Council of Canada (PR). We thank M. Ort and R. Brown for their reviews and feedback on a previous version of the manuscript. 
emplacement of Eocene intrusions into Cretaceous to Eocene strata, TransPecos igneous province, West Texas. J. Volcanol. Geotherm. Res. 181, 155-172. doi: 10.1016/j.jvolgeores.2008.12.017

Begét, J. E., Hopkins, D. M., and Charron, S. D. (1996). The largest known maars on Earth, Seward Peninsula, northwest Alaska. Arctic 49, 62-69. doi: 10.14430/arctic1184

Blaikie, T. N., Ailleres, L., Cas, R. A. F., and Betts, P. G. (2012). Threedimentional potential field modelling of a multi-vent maar-diatreme - The Lake Coragulac maar, Newer Volcanics Province, south-eastern Australia. J. Volcanol. Geotherm. Res. 235-236, 70-83. doi: 10.1016/j.jvolgeores.2012.05.002

Brown, R. J., and Valentine, G. A. (2013). Physical characterstics of kimberlite and basaltic intraplate volcanism and implications of a biased kimberlite record. Geol. Soc. Am. Bull. 125, 1224-1238. doi: 10.1130/B30749.1

Clarke, H., Troll, V. R., and Carracedo, J. C. (2009). Phreatomagmatic to Strombolian eruptive activity of basaltic cinder cones: Montaña Los Erales, Tenerife, Canary Islands. J. Volcanol. Geotherm. Res. 180, 225-245. doi: 10.1016/j.jvolgeores.2008.11.014

Delpit, S., Ross, P.-S., and Hearn, B. C. Jr. (2014). Deep-bedded ultramafic diatremes in the Missouri River Breaks volcanic field, Montana, USA: $1 \mathrm{~km}$ of syn-eruptive subsidence. Bull. Volcanol. 76:832. doi: 10.1007/s00445-014-0832-8

Diez, M., Connor, C. B., Kruse, S. E., Connor, K., and Savov, I. P. (2009). Evidence of small-volume igneous diapirism in the shallow crust of the Colorado Plateau, San Rafael Desert, Utah. Lithosphere 1, 328-336. doi: 10.1130/L61.1

Fisher, R. V., and Waters, A. C. (1970). Base surge bed forms in maar volcanoes. Am. J. Sci. 268, 157-180. doi: 10.2475/ajs.268.2.157

Goto, A., Taniguchi, H., Yoshida, M., Ohba, T., and Oshima, H. (2001). Effects of explosion energy and depth to the formation of blast wave and crater: field explosion experiment for the understanding of volcanic explosion. Geophys. Res. Lett. 28, 4287-4290. doi: 10.1029/2001GL013213

Graettinger, A. H., Valentine, G. A., and Sonder, I. (2015a). Circum-crater variability of deposits from discrete, laterally and vertically migrating volcanic explosions: experimental evidence and field implications. J. Volcanol. Geotherm. Res. 308, 61-69. doi: 10.1016/j.jvolgeores.2015.10.019

Graettinger, A. H., Valentine, G. A., Sonder, I., Ross, P.-S., and White, J. D. L. (2015b). Facies distribution of ejecta in analog tephra rings from experiments with single and multiple subsurface explosions. Bull. Volcanol. 77:66. doi: 10.1007/s00445-015-0951-x

Graettinger, A. H., Valentine, G. A., Sonder, I., Ross, P.-S., White, J. D. L., and Taddeucci, J. (2014). Maar-diatreme geometry and deposits: subsurface blast experiments with variable explosion depth. Geochem. Geophys. Geosyst. 15, 740-764. doi: 10.1002/2013GC005198

Hearn, B. C. Jr. (1968). Diatremes with kimberlitic affinities in north-central Montana. Science 159, 622-625. doi: 10.1126/science.159.3815.622

Houghton, B. F., and Smith, R. T. (1993). Recycling of magmatic clasts during explosive eruptions: estimating the true juvenile content of phreatomagmatic volcanic deposits. Bull. Volcanol. 55, 414-420. doi: 10.1007/BF00302001

Jordan, S. C., Cas, R. A. F., and Hayman, P. C. (2013). The origin of a large $(>3 \mathrm{~km})$ maar volcano by coalescence of multiple shallow craters: lake Purrumbete maar, southeastern Australia. J. Volcanol. Geotherm. Res. 254, 5-22. doi: 10.1016/j.jvolgeores.2012.12.019

Kurszlaukis, S., and Fulop, A. (2013). Factors controlling the internal facies architecture of maar-diatreme volcanoes. Bull. Volcanol. 75:761. doi: 10.1007/s00445-013-0761-y

Lefebvre, N. S., White, J. D. L., and Kjarsgaard, B. A. (2012). Spatter-dike reveals subterranean magma diversions: consequences for small multivent basaltic eruptions. Geology 40, 423-426. doi: 10.1130/G32794.1

Lefebvre, N. S., White, J. D. L., and Kjarsgaard, B. A. (2013). Unbedded diatreme deposits reveal maar-diatreme-forming eruptive processes: standing Rocks West, Hopi Buttes, Navajo Nation, USA. Bull. Volcanol. 75:739. doi: 10.1007/s00445-013-0739-9

Lefebvre, N. S., White, J. D. L., and Kjarsgaard, B. A. (2016). Arrested diatreme development: standing rocks East, Hopy Buttes, Navajo Nation, USA. J. Volcanol. Geotherm. Res. 310, 186-208. doi: 10.1016/j.jvolgeores.2015.12.007

Lorenz, V. (1986). On the growth of maars and diatremes and its relevance to the formation of tuff rings. Bull. Volcanol. 48, 265-274. doi: 10.1007/BF01081755

McClintock, M. (2006). Physical Volcanology of the Sterkspruit flood basalt crater complex, South Africa. Dissertation, University of Otago, Dunedin.
McGetchin, T. R., and Ullrich, G. W. (1973). Xenoliths in maars and diatremes, with references for the moon, Mars and Venus. J. Geophys. Res. 78, 1832-1852. doi: 10.1029/JB078i011p01833

Moore, J. G., Nakamura, K., and Alcaraz, A. (1966). The 1965 eruption of Taal Volcano. Science 151, 955-960. doi: 10.1126/science.151.3713.955

Muirhead, J. D., Van Eaton, A. R., Re, G., and White, J. D. L. (2016). Monogenetic volcanoes fed by interconnected dikes and sills in the Hopi Buttes volcanic field, Navajo Nation, USA. Bull. Volcanol. 78:11. doi: 10.1007/s00445-016-1005-8

Re, G., White, J. D. L., Muirhead, J. D., and Ort, M. H. (2016). Subterranean fragmentation of magma during conduit initiation and evolution in the shallow plumbing system of the small-volume Jagged Rocks volcanoes (Hopi Buttes Volcanic Field, Arizona, USA). Bull. Volcanol. 78:55. doi: 10.1007/s00445-016-1050-3

Ross, P.-S., Carrasco Núñez, G., and Hayman, P. (2017). Felsic maar-diatreme volcanoes: a review. Bull. Volcanol. 79:20. doi: 10.1007/s00445-016-1097-1

Ross, P.-S., and White, J. D. L. (2006). Debris jets in continental phreatomagmatic volcanoes: a field study of their subterranean deposits in the Coombs Hills vent complex, Antarctica. J. Volcanol. Geotherm. Res. 149, 62-84. doi: 10.1016/j.jvolgeores.2005.06.007

Ross, P.-S., White, J. D. L., Zimanowski, B., and Büttner, R. (2008a). Rapid injection of particles and gas into non-fluidized granular material, and some volcanological implications. Bull. Volcanol. 70, 1151-1168. doi: 10.1007/s00445-008-0230-1

Ross, P.-S., White, J. D. L., Zimanowski, B., and Büttner, R. (2008b). Multiphase flow above explosion sites in debris-filled volcanic vents: Insights from analogue experiments. J. Volcanol. Geotherm. Res. 178, 104-112. doi: 10.1016/j.jvolgeores.2008.01.013

Self, S., Kienle, J., and Huot, J.-P. (1980). Ukinrek Maars, Alaska, II. Deposits and formation of the 1977 craters. J. Volcanol. Geotherm. Res. 7, 39-65. doi: 10.1016/0377-0273(80)90019-0

Sohn, Y. K., and Chough, S. K. (1989). Depositional processes of the Suwolbong tuff ring, Cheju Island (Korea). Sedimentology 36, 837-855. doi: 10.1111/j.1365-3091.1989.tb01749.x

Sonder, I., Graettinger, A. H., and Valentine, G. A. (2015). Scaling multiblast craters: general approach and applications to volcanic craters. J. Geophys. Res. 120, 6141-6158. doi: 10.1002/2015JB012018

Sparks, R. S. J., Baker, L., Brown, R. J., Field, M., Schumacher, J., Stripp, G., et al. (2006). Dynamical constraints on kimberlite volcanism. J. Volcanol. Geotherm. Res. 155, 18-48. doi: 10.1016/j.jvolgeores.2006.02.010

Sweeney, M. R., and Valentine, G. A. (2015). Transport and mixing dynamics from explosions in debris-filled volcanic conduits: numerical results and implications for maar-diatreme volcanoes. Earth Planet. Sci. Lett. 425, 64-76. doi: 10.1016/j.epsl.2015.05.038

Taddeucci, J., Sottili, G., Palladino, D. M., Ventura, G., and Scarlato, P. (2010). A note on maar eruption energetics: current models and their application. Bull. Volcanol. 72, 75-83. doi: 10.1007/s00445-009-0298-2

Taddeucci, J., Valentine, G. A., Sonder, I., White, J. D. L., Ross, P.-S., and Scarlato, P. (2013). The effect of pre-existing craters on the initial development of explosive volcanic eruptions: an experimental investigation. Geophys. Res. Lett. 40, 507-510. doi: 10.1002/grl.50176

Valentine, G. A., Graettinger, A. H., Macorps, E., Ross, P.-S., White, J. D. L., Döhring, E., et al. (2015). Experiments with vertically- and laterally-migrating subsurface explosions with applications to the geology of phreatomagmatic and hydrothermal explosion craters and diatremes. Bull. Volcanol. 77, 15. doi: 10.1007/s00445-015-0901-7

Valentine, G. A., Graettinger, A. H., and Sonder, I. (2014). Explosion depths for phreatomagmatic eruptions. Geophys. Res. Lett. 41, 3045-3051. doi: 10.1002/2014GL060096

Valentine, G. A., and Krogh, K. E. C. (2006). Emplacement of shallow dikes and sills beneath a small basaltic volcanic center - the role of pre-existing structure (Paiute Ridge, southern Nevada, USA). Earth Planet. Sci. Lett. 246, 217-230. doi: 10.1016/j.epsl.2006.04.031

Valentine, G. A., Shufelt, N. L., and Hintz, A. R. L. (2011). Models of maar volcanoes, Lunar Crater (Nevada, USA). Bull. Volcanol. 73, 753-765. doi: 10.1007/s00445-011-0451-6

Valentine, G. A., and van Wyk de Vries, B. (2014). Unconventional maar diatreme and associated intrusions in the soft sediment-hosted Mardoux structure (Gergovie, France). Bull. Volcanol. 76:807. doi: 10.1007/s00445-014-0807-9 
Valentine, G. A., and White, J. D. L. (2012). Revised conceptual model for maardiatremes: subsurface processes, energetics, and eruptive products. Geology 40, 1111-1114. doi: 10.1130/G33411.1

White, J. D. L. (1991). Maar-diatreme phreatomagmatism at Hopi Buttes, Navajo Nation (Arizona), USA. Bull. Volcanol. 53, 239-258. doi: 10.1007/BF004 14522

White, J. D. L., and McClintock, M. K. (2001). Immense vent complex marks flood-basalt eruption in a wet, failed rift: Coombs Hills, Antarctica. Geology 29, 935-938. doi: 10.1130/0091-7613(2001)029<0935:IVCMFB >2.0.CO;2

White, J. D. L., and Ross, P.-S. (2011). Maar-diatreme volcanoes: a review. J. Volcanol. Geotherm. Res. 201, 1-29. doi: 10.1016/j.jvolgeores.2011. 01.010

White, J. D. L., and Valentine, G. A. (2016). Magmatic versus phreatomagmatic fragmentation: absence of evidence is not evidence of absence. Geosphere 12, 1478-1488. doi: 10.1130/GES01337.1
Woolsey, T. S., McCallum, M. E., and Schumm, S. A. (1975). Modeling of diatreme emplacement by fluidization. Phys. Chem. Earth 9, 30-42. doi: 10.1016/0079-1946(75)90004-X

Conflict of Interest Statement: The authors declare that the research was conducted in the absence of any commercial or financial relationships that could be construed as a potential conflict of interest.

Copyright (C) 2017 Valentine, White, Ross, Graettinger and Sonder. This is an openaccess article distributed under the terms of the Creative Commons Attribution License (CC BY). The use, distribution or reproduction in other forums is permitted, provided the original author(s) or licensor are credited and that the original publication in this journal is cited, in accordance with accepted academic practice. No use, distribution or reproduction is permitted which does not comply with these terms. 